\title{
Pulse Power Generator Design for Machining Micro-pits on Hip Implant
}

\author{
Nazriah Mahmud ${ }^{a *}$, Azli Yahya ${ }^{a}$, Mohammed Rafiq Abdul Kadir ${ }^{a}$, Nor Liyana Safura Hashim ${ }^{a}$ \\ ${ }^{a}$ Faculty of Health Science and Biomedical Engineering, Universiti Teknologi Malaysia, 81310 Johor Bahru, Johor, Malaysia \\ *Corresponding author: nazriah2@yahoo.com
}

\section{Article history}

Received :31 May 2012

Received in revised form :30 July

2012

Accepted :5 January 2013

Graphical abstract

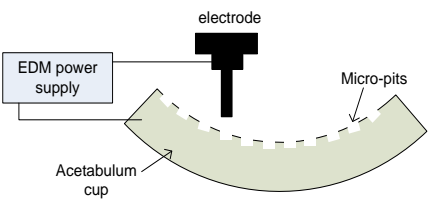

\section{Abstract}

Machining micro-pits on hip implant for lubrication purpose is the most effective way to minimize wear as well as prolong the lifespan of the hip implant. Several works on designing Pulse Power Generator for machining micro-pits has been conducted but suffer from micro crack. Thus, in this research, a new design of Electrical Discharge Machining Pulse Power Generator is implemented which consist of Flyback converter circuit and Current Mode Controller Integrated Circuit. The work involves the design and development of the SIMULINK behavior model of the overall system. The machining performance of the system is evaluated by changing the input voltage.

Keywords: Flyback converter; micro-pits; hip implant; electrical discharge machining

Abstrak

Pemesinan lubang-lubang mikro pada implan pinggul bagi tujuan pelinciran adalah cara terbaik bagi mengurangkan kehausan dan juga memanjangkan jangka hayat implan tesebut. Beberapa kerja-kerja mereka bentuk penjana kuasa untuk pemesinan lubang-lubang mikro telah dijalankan tetapi mengalami kegagalan disebabkan oleh keretakan mikro. Justeru, dalam projek ini, rekabentuk baru bagi pemjana kuasa dilaksanakan yang terdiri daripada 'flyback converter' dan litar bersepadu mod kawalan arus. Projek ini melibatkan reka bentuk keseluruhan model menggunakan SIMULINK. Prestasi pemesinan menggunakan sistem ini dinilai dengan menukar voltan masukan.

Kata kunci: Flyback converter; lubang-lubang mikro; implan pinggul

(C) 2012 Penerbit UTM Press. All rights reserved.

\subsection{INTRODUCTION}

Hip implant or hip replacement become necessary when the hip joint has been badly damaged, more often in aged people or by chronic pain or disease. Around 1960's, the materials commonly employed in hip implant is metal-on-plastic (MoP), with cobalt chromium alloy head paired with a plastic cup. ${ }^{1}$ However, these materials combination suffer from wear whose debris generates an adverse tissue reaction. As the alternative, in late 1980's metalon-metal hip implant has been reintroduced. ${ }^{2}$ This second generation of metal-on-metal hip implants improved bearing geometry and surface finish by promoting lubrication through surface texturing. It has been reported that dimples on surface may provide lubrication pockets to protect direct surface to surface contacts and reduce wear. ${ }^{3}$ A micro-pits formation is therefore proposed for lubrication purpose, which eventually prolong the lifespan of the hip implant.

In theory, Micro Electrical Discharge Machining (Micro EDM) would suitable for this application due to its non-contact process between the electrode and the workpiece. In commercial Micro EDM application, a low current of RC generator would normally be applied. But the pulse energy in discharge process is uncontrollable. The machined parts would suffer from micro crack; melted electrode and left over debris. Thus, machining micro-pits using new design of pulse power generator using controllable chip to control the pulse generation, will overcome the drawback of commercial pulse power generator.

In this project, Switch Mode Power Supply (SMPS) will be implemented in order to design the new Pulse Power Generator (PPG) for machining micro-pits on hip implant. This paper focuses on designing new PPG unit, which consist of Flyback conveter SMPS and a commercial Pulse-Width Modulation Integrated Circuit (IC). A MATLAB/SIMULINK behavior modeling technique for flyback converter and control ICs is presented. Simulation results are provided to demonstrate the efficiency of the proposed model.

\subsection{EDM PULSE POWER GENERATOR}

In EDM process, power supply plays a vital role in providing thermal action between the electrode and workpiece. There are two types of power supplies that have received most attention in EDM process. There are resistance-capacitance generator and pulse generator. ${ }^{4}$ Due to development in electronics and power system, several power supplies have been developed for various 
EDM applications. Table 1 discusses the recent development of power supply used in EDM process.

Table 1 Development of power generator used in EDM process

\begin{tabular}{|c|c|c|}
\hline Author/Year & Type of Power Supply & Advantages \\
\hline $\begin{array}{l}\text { Casanueva et al., } \\
2000^{5}\end{array}$ & $\begin{array}{l}\text { current mode controlled series } \\
\text { inductor, series parallel } \\
\text { capacitor (lcc) resonant } \\
\text { converter }\end{array}$ & $\begin{array}{l}\text { inherent protection under short } \\
\text { circuit condition, robust feedback } \\
\text { controller against load changes } \\
\text { and high efficiency }\end{array}$ \\
\hline $\begin{array}{l}\text { Casanueva et al., } \\
2001^{6}\end{array}$ & $\begin{array}{l}\text { current source lcc resonant } \\
\text { converter }\end{array}$ & $\begin{array}{l}\text { necessary over voltage to } \\
\text { ionize the dielectric and } \\
\text { constant current supplied } \\
\text { provide inherent protection } \\
\text { under short circuit condition }\end{array}$ \\
\hline $\begin{array}{l}\text { Casanueva et al., } \\
2004^{7}\end{array}$ & $\begin{array}{l}\text { high frequency switched dc to } \\
\text { dc series parallel resonant } \\
\text { converter }\end{array}$ & $\begin{array}{l}\text { suitable to be used for } \\
\text { nuclear power plant } \\
\text { application }\end{array}$ \\
\hline $\begin{array}{l}\text { Casanueva et al., } \\
\qquad 2008^{8}\end{array}$ & $\begin{array}{l}\text { high frequency resonant } \\
\text { inverter as ac current source }\end{array}$ & $\begin{array}{l}\text { minimize electrolysis effect on the } \\
\text { workpiece and prevent reverse } \\
\text { discharge }\end{array}$ \\
\hline $\begin{array}{c}\text { Aparna and } \\
\text { Kasirathi, } 2011^{9}\end{array}$ & $\begin{array}{l}\text { series parallel resonant } \\
\text { converter }\end{array}$ & $\begin{array}{c}\text { smaller size and lower power } \\
\text { losses }\end{array}$ \\
\hline
\end{tabular}

As discuss in Table 1, the existing power supplies are unsuitable for low power application. Therefore, fly-back SMPS is implemented in this study because of its advantages over linear regulators. This is because, for output power levels less than 150 $\mathrm{W}$, the design of the power transformer is relatively simple. Beside, total cost for the fly-back SMPS are low due to low component count. In addition only one magnetic element (flyback transformer) is used as no inductors are used in the output filter. It also has wide input voltage range as well as multiple outputs can be obtained using a minimum number of parts.

\subsection{MICRO-PITS}

Micro-pits (also known as dimples, holes, oil pocket or cavities) widely known able to reduce wear through lubrication, but there is a little information about the effect of micro-pits in artificial human joint for lubrication purpose. As reported in, ${ }^{10}$ the micropits may reduce friction in two ways: by providing lift themselves as a micro hydrodynamics bearing, and by acting as reservoir of lubricant. M. Wakuda also agreed that micro-dimples surface texture was helpful to reduce friction on pin-on-plane experiment. ${ }^{11}$ In, ${ }^{12}$ various positions and depth of micro-pits on the hip implant has been proposed to ease friction between metalon-metal surfaces joint. Thus, in this research the designed PPG will be implemented to machine the micro-pits as illustrated in Figure 1. These micro-pits will be act as the reservoir of lubricant as well as improve friction between contact surfaces.

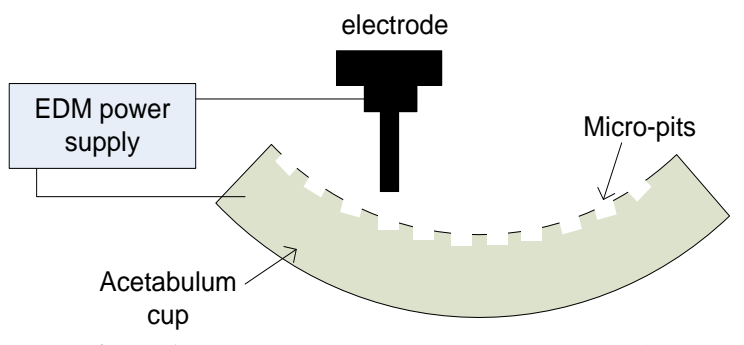

Figure 1 Micro-pits machined with good surface finish

\subsection{METHODOLOGY}

\subsection{System Block Diagram}

The block diagram in Figure 2 shows the overall system of Switch Mode Power Supply (SMPS). The input voltage is rectified and filtered by the input capacitor. The DC voltage applied to DC-DC converter. Regulation of the output is carried out by the control/feedback block, which can be implemented using a commercial pulse-width modulation (PWM) IC. There are several topologies used in DC-DC converter and there are a large variety of PWM ICs are suitable for these topologies. In this project, flyback converter is applied and UC3843 ICs is chosen as the PWM controller. A MATLAB/SIMULINK model of the system is then presented. 


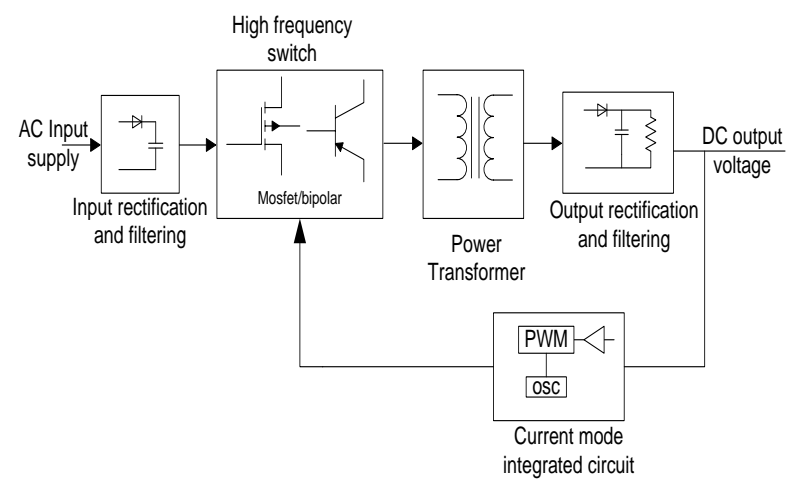

Figure 2 Block diagram of switch mode power supply

\subsection{Pulse Power Generator using Flyback Converter}

Figure 3 shows the flyback converter circuit and the behavior modeling technique as presented in ${ }^{13}$ is adopted. The complete operation principle of flyback converter circuit is explained by referring to the equivalent circuit in Figure 4 and 5 respectively.

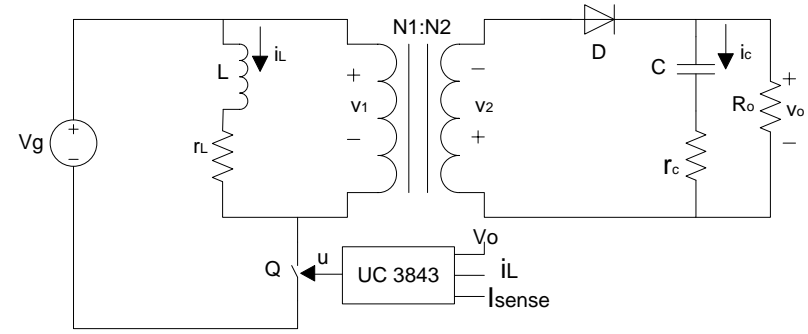

Figure 3 Flyback converter model with magnetizing inductance

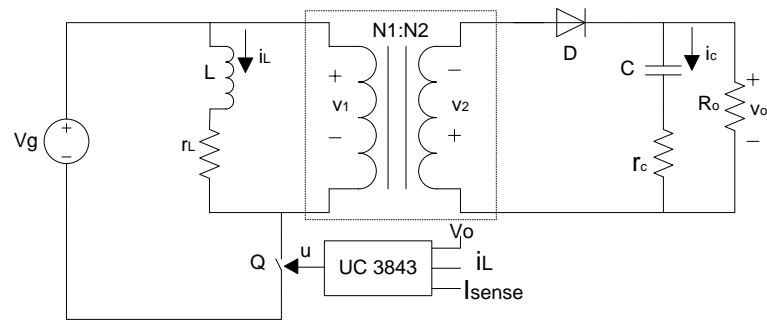

Figure 4 Equivalent flyback circuit when Switch $\mathrm{Q}$ is on

In Figure 4 when Switch Q is on, the input voltage feed the energy to the primary winding of the transformer. At this time the diode reverse biased due to the induced voltage in secondary winding. Thus, by turning on Switch $\mathrm{Q}$, primary winding is able to carry current. The load current is offered by the capacitor storage energy at previous switching period. The state equations when Switch Q is on can be written as

$$
\begin{aligned}
& \frac{d i_{L}}{d t}=\frac{1}{L}\left(v_{g}-i_{L} r_{L}\right) \\
& \frac{d v_{c}}{d t}=-\frac{1}{C} \frac{V_{o}}{R_{o}}
\end{aligned}
$$

On the load side of transformer the relationship between voltage on the primary side and secondary side can be shown as:

$$
\begin{aligned}
& v_{1}=v_{g} \\
& v_{2}=-v_{1}\left(\frac{N_{2}}{N_{1}}\right)=-v_{g}\left(\frac{N_{2}}{N_{1}}\right)
\end{aligned}
$$

where $N_{l}$ is the number of turns of primary side and $N_{2}$ is the number of turn of secondary side.

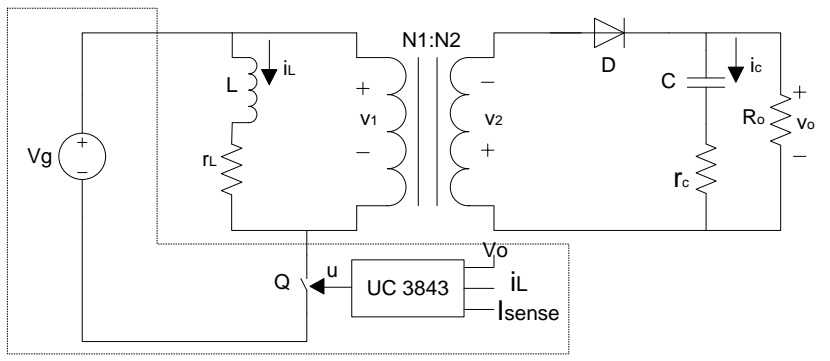

Figure 5 Equivalent flyback circuit when Switch Q is 'off'

In Figure 5 when Switch Q is off, the input voltage does not feed the energy to the primary winding of the transformer. Primary side inductance produces back electromotive voltage and opposed current change. Reversal of voltage polarities in secondary winding makes the diode forward biased, thus offers current to capacitor and load. At this time, the primary side of inductance current decreases until the Switch Q is on again. The state equations when Switch Q is off can be written as

$$
\begin{aligned}
& \frac{d i_{L}}{d t}=\frac{1}{L}\left(-\frac{N_{1}}{N_{2}} v_{o}-i_{L} r_{L}\right) \\
& \frac{d v_{c}}{d t}=\frac{1}{C}\left(\frac{N_{1}}{N_{2}} i_{L}-\frac{V_{o}}{R_{o}}\right)
\end{aligned}
$$

The relationship between $v_{l}$ and $v_{2}$ is

$$
\begin{aligned}
& v_{1}=-V_{o}\left(\frac{N_{1}}{N_{2}}\right), \text { but } v_{2}=-V_{o} \\
& v_{1}=v_{2}\left(\frac{N_{1}}{N_{2}}\right)
\end{aligned}
$$

The output voltage $V_{o}$ for switch on and off is the same

$$
v_{o}=i_{c} r_{c}+v_{c}
$$

The flyback converter work cycle by cycle. The system block diagram of flyback converter in MATLAB/SIMULINK environment is implemented based on Eq. (1)-(2) when Switch Q is on and Eq. (5) to (6) when Switch Q is off.

\subsection{Current Mode PWM Controller, UC3843}

There are many commercially available controller ICs. Here, UC3843 is taken as the PWM controller ICs. As seen in the block diagram of UC3843 ${ }^{14}$ in Figure 6, the ICs consists of error amplifier, a PWM comparator and an S-R flip flop. This IC provides good electrical performance in current mode operation with minimal cost. It is optimized for efficient power sequencing of off-line converters, DC to DC regulators and for driving power MOSFETs or transistors. The MATLAB/SIMULINK model is presented based on the block diagram. 


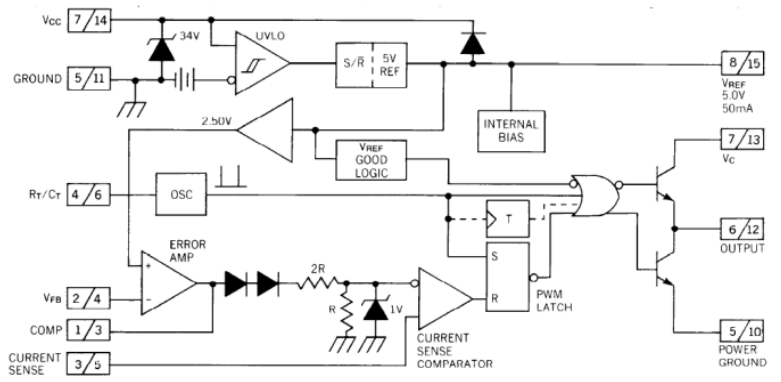

Figure 6 Block diagram of UC3843

\subsection{RESULT AND ANALYSIS}

The MATLAB/SIMULINK model is divided into two subsystems which are flyback converter and PWM controller Integrated Circuit (ICs) as shown in Figure 7. The subsystem of flyback converter and UC3843 SIMULINK model is presented in Figure 8 and 9 respectively. The load is modelled as the resistor, $R_{0}$.

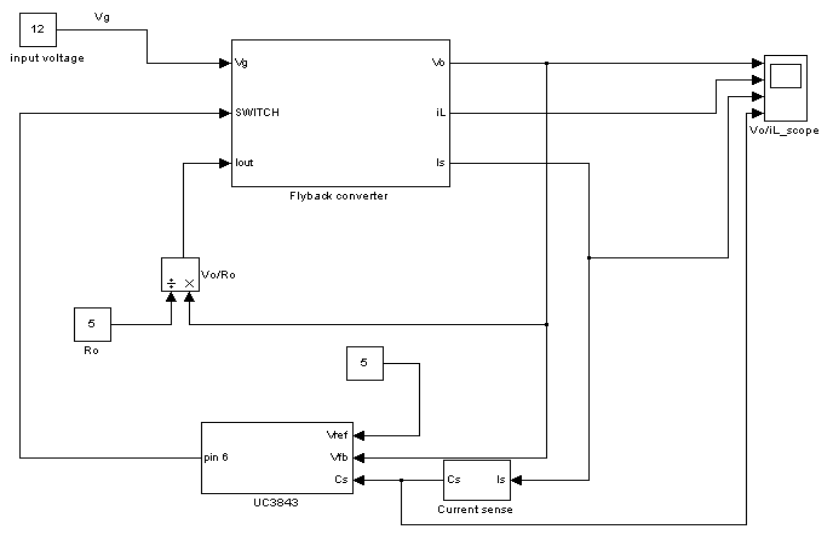

Figure 7 The overall modeling system of SMPS

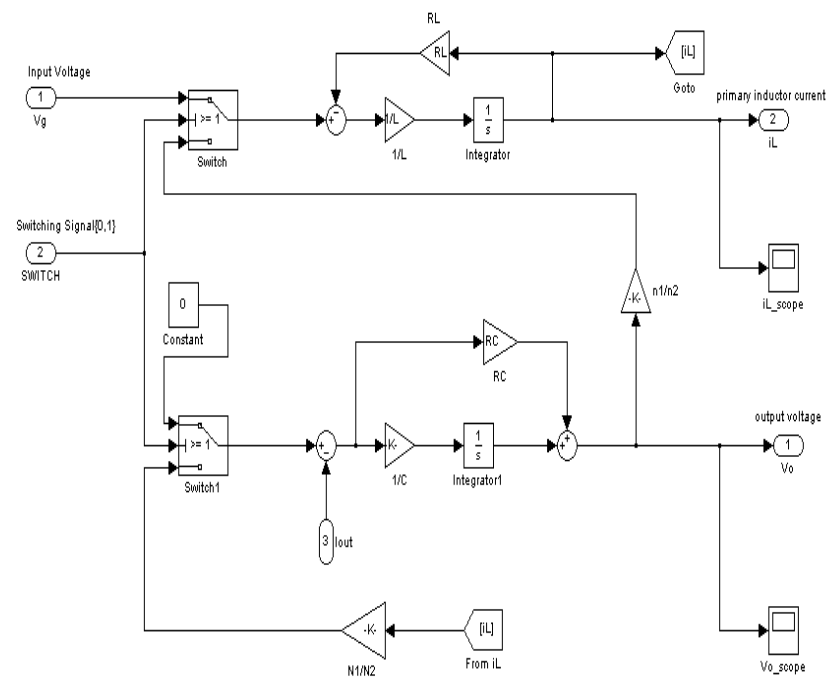

Figure 8 The flyback converter model
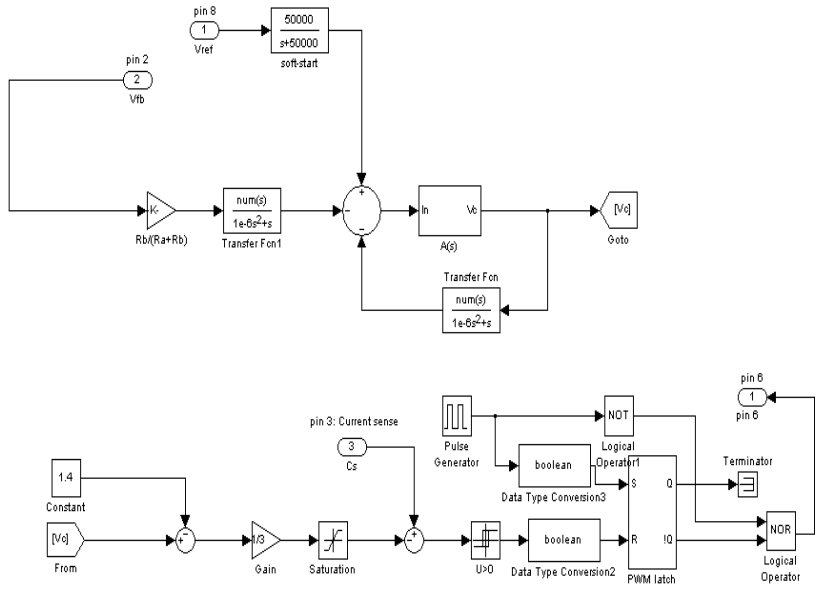

Figure 9 The UC3843 IC's model

The parameters used in the simulation for flyback converter circuit are shown in the Table 2.

Table 2 Parameter for flyback converter circuit

\begin{tabular}{ll}
\hline \multicolumn{1}{c}{ Parameter } & Values \\
\hline Magnetizing Inductance & $500 \mu \mathrm{H}$ \\
Primary winding ratio & 2 \\
Secondary winding ratio & 1 \\
Input voltage & $36-90 \mathrm{~V}$ \\
Output resistor & $5 \Omega$ \\
Sampling frequency & $100 \mathrm{kHz}$ \\
Inductor resistance & $10 \mu \Omega$ \\
Capacitor & $200 \mu \mathrm{F}$ \\
\hline
\end{tabular}

The input voltage was varied as $36 \mathrm{~V}, 50 \mathrm{~V}$ and $90 \mathrm{~V}$ with other parameters are fix. Figures 10-12 show simulated results by varying the input voltage. The simulated results are analyzed based on primary inductor current, iL and output voltage, Vo. The simulation results is viewed using a scope and the results is evaluated over running time. From the results, as the system achieved steady state, the output voltage regulated and maintain at that value.

\subsection{CONCLUSION}

In this paper, a simulation model utilizing MATLAB/SIMULINK technique has been developed to evaluate the performance of flyback converter topology for Micro-EDM pulse power generator. From the simulation results acquired, the fly-back SMPS has successfully modeled to analyze the efficiency of the proposed design. Later, a hardware design of fly-back SMPS will be carried out for machining micro pits on hip implant with minimal surface crack as well as eliminated the melted stray of eroded material. 


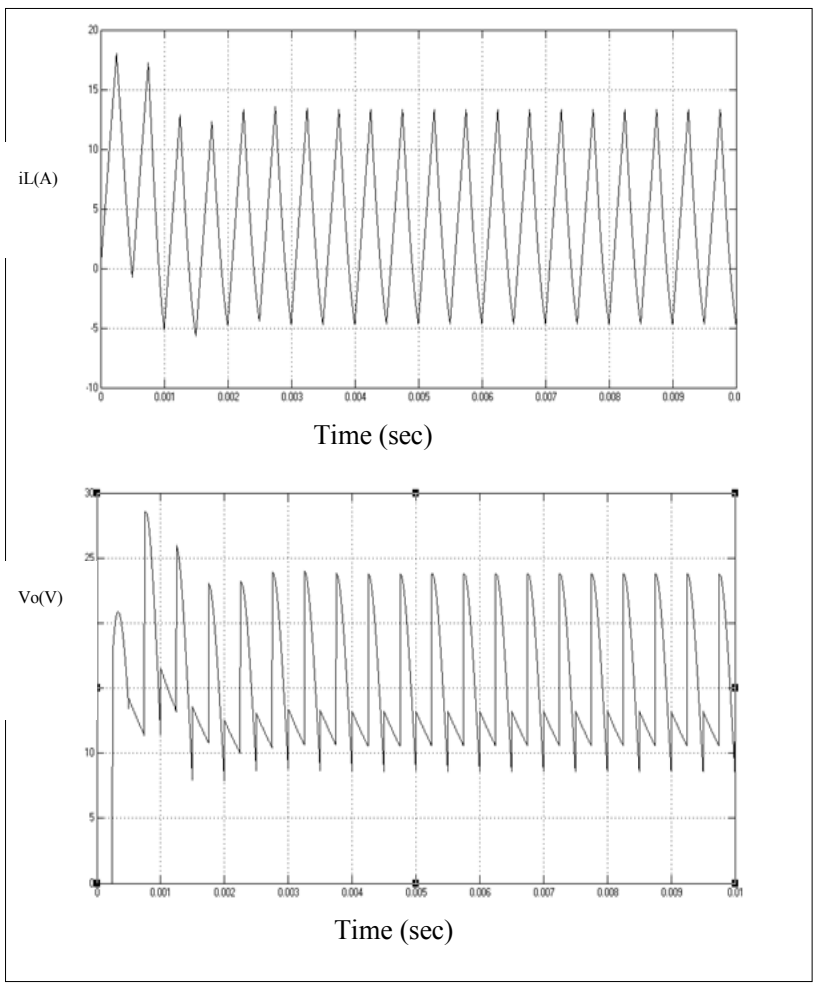

Figure 10 Primary inductance current, $i_{L}$ and $V_{o}$ with $V_{i n}=36 V$

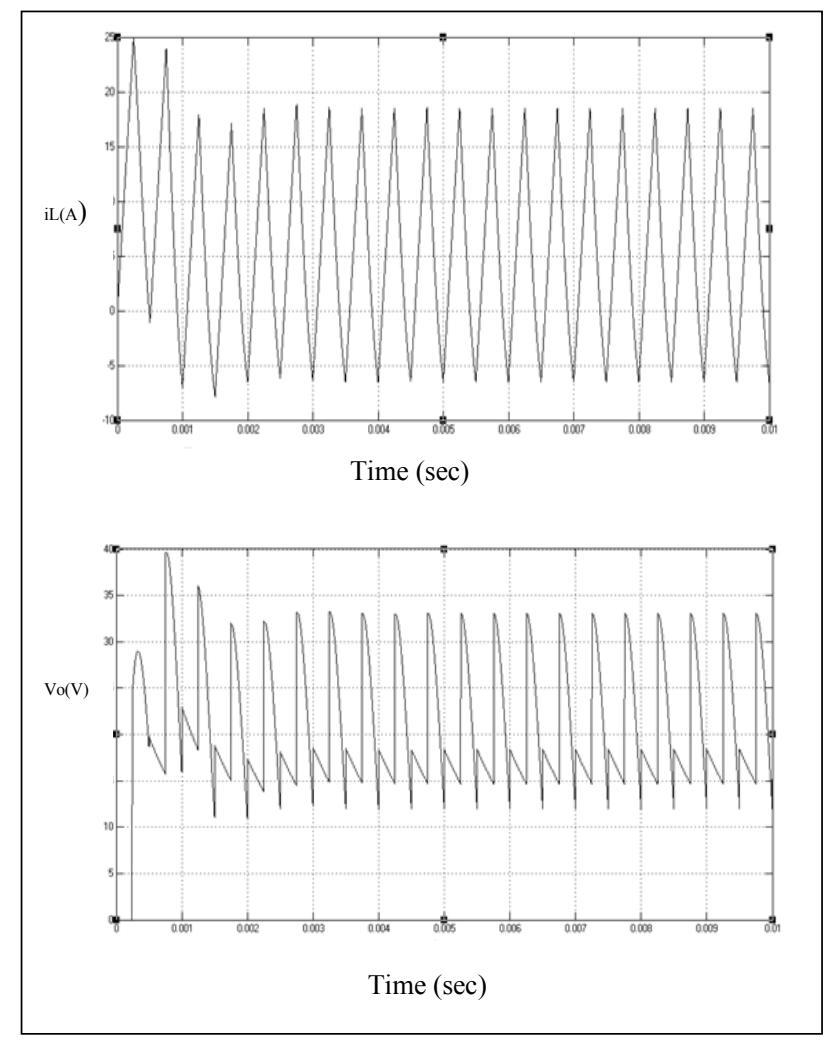

Figure 11 Primary inductance current, $\mathrm{i}_{\mathrm{L}}$ and $\mathrm{V}_{\mathrm{o}}$ with $\mathrm{V}_{\text {in }}=50 \mathrm{~V}$

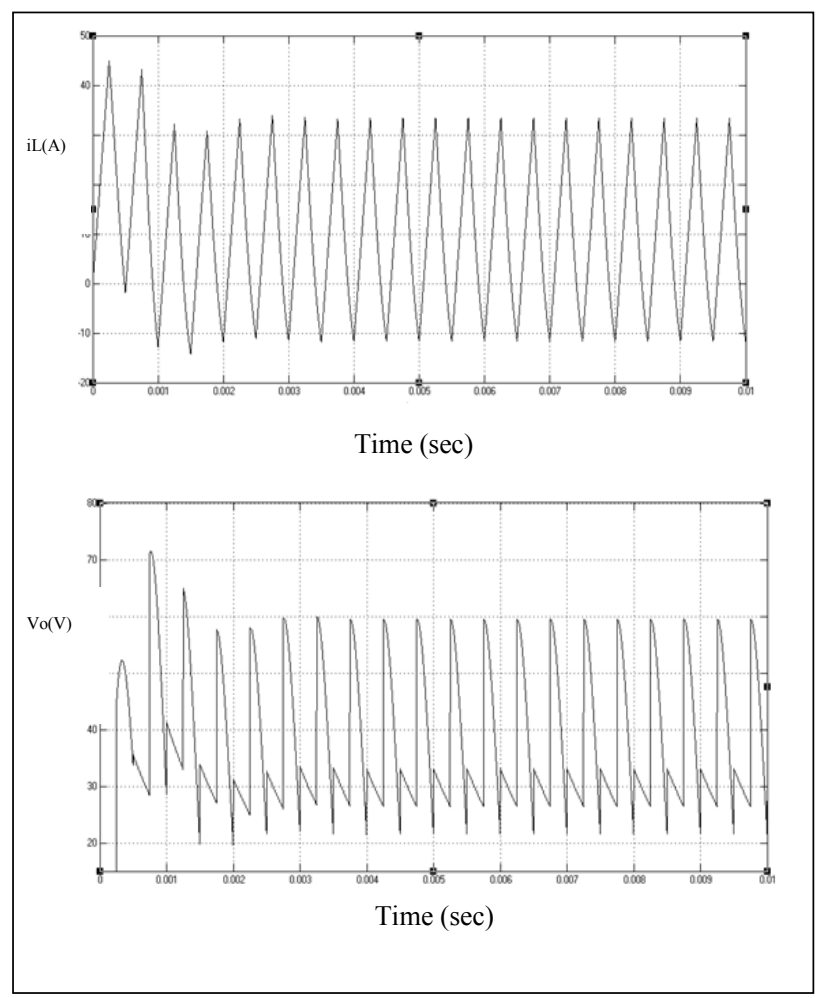

Figure 12 Primary inductance current, $i_{L}$ and $V_{o}$ with $V_{\text {in }}=90 \mathrm{~V}$

\section{Acknowledgement}

This paper is a part of a publication series on Research and Development in Signal, Image and Sensors in Biomedical Engineering Applications. The authors are indebted to Research Management Centre (RMC) Universiti Teknologi Malaysia for financial support.

\section{References}

[1] J. H. Dumbleton and M. T. Manley. 2005. Metal-on Metal Total Hip Replacement. The Journal of Arthroplasty. 20(2): 174-188.

[2] L. Mattei, F. D. Puccio, B. Piccigallo, E. Ciulli. 2011. Lubrication and Wear Modeling of Artificial Hip Joint: A Review. Tribology International. 44(5): 532-549.

[3] L. Gao, P. Yand, I. Dymond, J. Fisher and Z. Jin. 2010. Effect of Surface Texturing on the Elastohydrodynamic Lubrication Analysis of Metal-on Metal Hip Implants. Tribology International. 43(1): 1851-1860.

[4] B.Flemming. 2005. The EDM How-To Book. Fleming Publication.

[5] R. Casanueva, M. Ochoa, F. J. Azcondo, S. Bracho. 2000. Current Mode Controlled LCC Resonant Converter for Electrical Discharge Machining Applications. In Industrial Electronics, 2000. ISIE 2000. Proceedings of the 2000 IEEE International Symposium.

[6] R. Casanueva, L. A. Chiquito, F. J. Azcondo, S. Bracho. 2001. Current Source LCC Resonant Converter For An EDM Power Supply. In Industrial Electronics Society, 2001. IECON '01. The 27th Annual Conference of the IEEE.

[7] R. Casanueva, F. J. Azcondo, S. Bracho. 2004. Series-parallel Resonant Converter for an EDM Power Supply. Journal of Materials Processing Technology. 149: 172-177.

[8] R. Casanueva, F. J. Azcondo, C. Brañas. 2008. A New Bipolar Power Supply for Spark Erosion based on a Series-parallel Resonant Inverter. Applied Power Electronics Conference and Exposition, 2008. APEC 2008. Twenty-Third Annual IEEE.1904-1909.

[9] S. Aparna and N. Kasirathi. 2011. Series Parallel Resonant Converter for Electrical Discharge Machining Power Supply. In 2011 1st International Conference on Electrical Energy System. 28-33. 
[10] B. Nilson, R. B. G., T. R. Thomas, D. Wiklund, L. Xiao. 2004. Oil Pockets and Surface Topography: Mechanism of Friction Reduction. In Proceedings of the XI International Collaquium on Surfaces. Chemnitz, Germany.

[11] M. Wakuda, Y. Yamauchi, S. Kanzaki, Y. Yasuda. 2003. Effect of Surface Texturing on Friction Reduction Between Ceramic and Steel Materials Under Lubricated Sliding Contact. Wear. 254(3-4): 356-363.

[12] N. Mahmud, A. Yahya, M. Rafiq, S. Samion , N. L. Safura. 2012. Electrical Discharge Machining Pulse Power Generator to Machine
Micropits of Hip Implant. In International Conference on Biomedical Engineering. Bayview Beach Resort Penang, Malaysia: IEEE.

[13] W. H. Liao, S. C. Wang, and Y. H. Liu. 2009. Learning switched mode power supply design using MATLAB/SIMULINK. in TENCON 2009. IEEE Region 10 Conference.

[14] U. A. Note. 1999. UC3842/3/4/5 Provides Low Cost Current-mode Control, T. I. Incorporated Editor. 